\title{
Factors Affecting the Decision to Choose a Local University in Vietnam
}

\author{
Le Thi Thanh Thuy \\ Economics and BA Faculty of Hong Duc University, Vietnam \\ Email: 1thanhthuy@hdu.edu.vn
}

\author{
Article History \\ Received: December 22, 2019 \\ Revised: January 15, 2020 \\ Accepted: January 23, 2020 \\ Published: January 26, 2020 \\ Copyright (c) 2020 ARPG \& \\ Author \\ This work is licensed under the \\ Creative Commons Attribution \\ International \\ (c) (1) \\ Commons Attribution License \\ 4.0
}

\begin{abstract}
Most universities in Vietnam, especially the local ones, are struggling to implement the annual enrollment plan because their enrollment plans have not completed recently. What are the important factors affecting admissions results for local universities? On the basis of the theoretical model, the research has proposed, designed and tested the scale of factors affecting the decision to choose a local university in Vietnam. Through a survey of 412 students at local universities, the regression model showed that six groups of proposed factors influenced the decision on local university choice in Vietnam in descending order of impact as follows: Study Costs, Majors, Influence Group, Quality and Reputation, Facilities, Advertising and Operations. The research model explains $62.4 \%$ for the overall relationship of the above 6 groups of factors with the dependent variable, which is Decision of choosing local university in Vietnam.
\end{abstract}

Keywords: Local university; Decision; Influence; Factor; Vietnam.

\section{Introduction}

Since 2015, the Ministry of Education and Training of Vietnam has renovated university and college admissions methods and allowed universities all over the country to have autonomy in developing enrollment plans. Since then, the enrollment of universities and colleges across the country, especially local one has encountered many difficulties. Most universities are struggling to meet the annual enrollment plan, even if the enrollment plan is not complete. Among the local universities across the country, there are many schools that have been accredited by the Ministry of Education and Training but there has been a shortage of students despite the spacious facilities, the increasingly high-quality teaching staffs and friendly environment, and the professional leadership who used to hold key management roles in the education sector.

Although the enrollment advisory work of the universities has gone into depth and breadth, large in both the quantity and quality of advice, the number of candidates attending the local one has not increased ... There is an existing inverse that the author wants to find out the answer is that the local universities are growing in every aspect but the number of candidates registered to enroll and study in reality tends to decrease. What are the important factors affecting admissions results for local universities? This is a question that motivates the author to carry out the research "Factors affecting the decision to choose a local university in Vietnam". The results of the study will suggest solutions to contribute to improve the effectiveness of enrollment advice of local universities across the country.

\section{Literature Review and Research Model}

In Vietnam, local universities have officially been established and recognized as an integral part of the university system since 1997 but so far there is no official definition of the type of university. There are many different interpretations about the local university. According to author (Le Quang, 2013), "local university is a state university proposed to establish, invest, provide budget and direct under the local government; is a multi-level and multi-disciplinary institution, which is primarily vocational-oriented with all levels from elementary to graduate, meeting on-site human resources needs, serving the socio-economic development of the locality and the surrounding area".

Universities must develop their educational activities by understanding the specific needs of a range of individuals and groups who may have direct or indirect influence in achieving goals. According to Kotler and Fox (1995), universities are influenced by many groups of stakeholders and can be classified into sixteen main groups. The behavior of students and other stakeholders of universities is one of those aspects that also need to be researched. Issues such as expectations and choices of students are characteristic of consumer behavior in higher education. Students desire to have valuable information resources, so their satisfaction depends on the relationship between expectations and the perception of reality received (Sander et al., 2000). Similarly, understanding the 
rationale for choosing a university is important for developing organizational positioning (Maringe, 2006). Today, university applicants are no longer passive consumers, they are becoming more educated consumers who can make reasonable choices in choosing schools and choosing educated programs. The research of university choice through the decision-making process has been widely used (Hemsley-Brown and Oplatka, 2006). Chapman (1981), suggested that there are two groups of factors that influence the univerity choice. The first is the characteristics of the family and individual students. The second is some external influences that have specific influences such as influencing individuals, fixed characteristics of the university and the university's communication efforts with students. There are many studies used from the results of D.W. Chapman or develop other related models to study the factors affecting the decision on university choice of high school students.

Joseph (2010), proposed a conceptual framework model that influences students' choice of university in Malaysia. Research results have shown that students' decision to choose a university influenced by factors of "fixed characteristics of the university" include: location; education program; reputation; infrastructure; Tuition fees; financial support; employment opportunities and factors of "student communication team" include: advertising; representative of admission, exchange with high schools; visiting university campus. Dahari and Muhamad (2011) studied international student cases using sample of students in Malaysia. The research results showed that "programs offered" is the number one factor which influences overall international students' choice for a postgraduatestudy in Malaysia universities. There were some differences between students from Asian and Westerncountries in ranking the importance of those factors. MeiTang, WeiPan and Mark D. Newmeyer applied the Model of Occupational Social Development Theory (Hackett, 1994) to examine factors affecting the career choice trend of high school students. This study showed that factors such as: learning experience, ability to self-assess occupational competence, benefits and expected results in career development process influence the decision to choose a career. Bromley (2004), in a survey of 384 teenagers concluded that both school and family have direct or indirect effects on their career choices. Michael Borchert and concluded that the key factors influencing career choices of students at Germantown High School, Wisconsin, United States are: environment, opportunities and personal characteristics. In particular, the group of personal characteristics has the greatest influence on the career choices of high school students.

In Vietnam, according to the results of the study "Factors affecting students choosing Open University in Ho Chi Minh City" by Nguyen (2011), there are 7 factors that influence students' choice of schools, which all have a close relationship with each other, including: school's effort to transfer information; Quality of teaching and learning; Characteristics of the students themselves; Future work; Ability to pass into school; Relatives in family; Relatives outside the family. Research results of Tran and Cao (2009) at Vietnam National University Ho Chi Minh City with 227 responses showed that 5 factors including future employment opportunities; fixed characteristics factors of the university; personal factors of the student; personal factors that influence students' decisions and factors of available information that influence university decisions.

In general, there are many groups of factors influencing high school students' decision to select universities. However, to carry out this topic, the author will rely on the above research results but selectively, adjust and supplement to form a new research model that is suitable for the purpose of the research for regional universities. This research model is also built based on the theory of satisfaction refered to the scales that have been developed in the world such as SERQUAL (Zeithaml and Bitner, 1996), service quality and satisfaction (Parasuraman et al., 1991). These are adjusted and supplemented to suit the research purpose with 6 factors that may influence the decision to choose a local university in Vietnam: Training Majors, Quality and Reputation, Costs, Influence Group, Facilities and Geographic Location, Promotional Activities.

Figure-1. Research Model

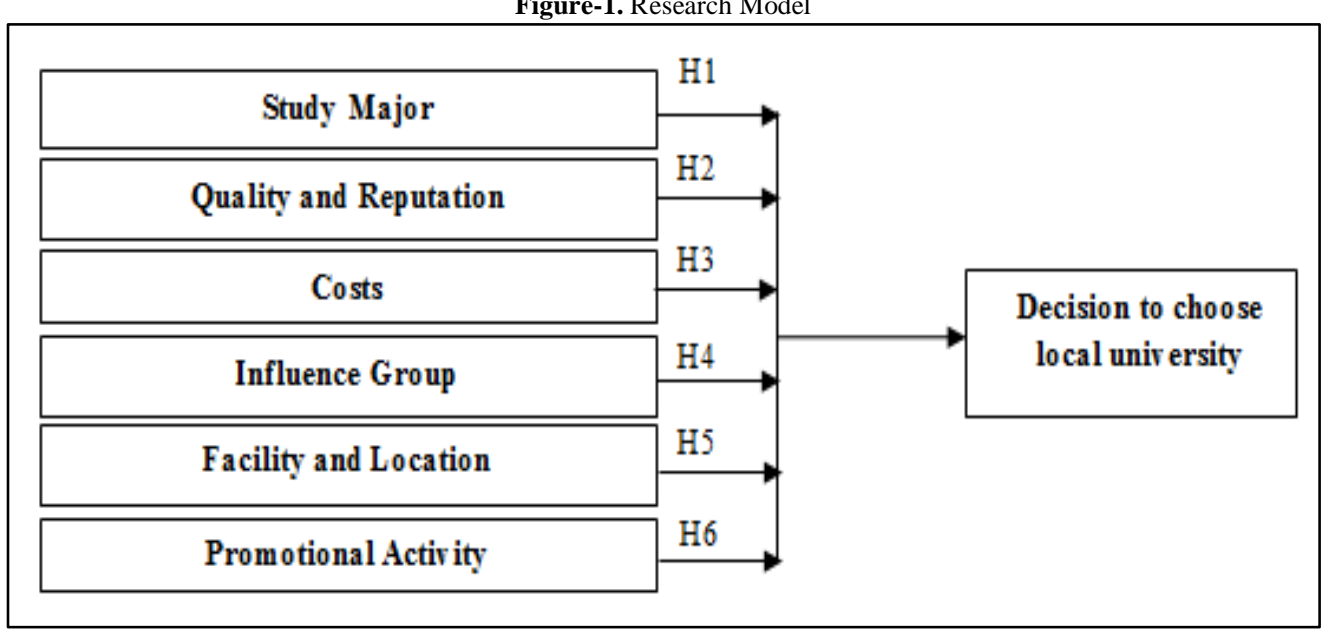

\section{Research Method}

Quantitative research was conducted through a sociological survey with a questionnaire designed for the purpose of considering and evaluating perspective of students who chosed to study at the local university. According to Hoang and Chu (2008), the sample size for EFA factor analysis must be at least 4 or 5 times the number of observed variables. In this study, there are 21 observed variables. The minimum sample size is 105 . Due to the 
limited conditions and resources, the author chooses a stratified, randomized sampling method with a sample size of 500. Although there are currently 22 local universities nationwide, however, the study only focused on local universities with over 10 years old and enrollment size of over 10,000 students. However, in order to ensure the representativeness of the sample, the author tries to choose sample units that are students from different schools with consideration to the subjects of different disciplines. The collected data is coded, cleaned and entered into SPSS 22.0 software, then analyzed through the steps of descriptive statistical analysis, factor analysis, reliability verification, correlation analysis and regression.

\section{Research Result and Discussion}

The number of questionnaires issued is 500. The number of votes collected is 421 . After checking, there are 9 invalid questionnaires. Therefore, the number of valid responses used in the data analysis is 412 . The number of answers ensure the minimum sample size for analysis.

Table-1. Information of respondents

\begin{tabular}{|c|c|c|c|c|c|c|c|}
\hline \multicolumn{2}{|c|}{ Respondents } & \multirow{2}{*}{$\frac{\text { Total }}{227}$} & \multirow{2}{*}{$\begin{array}{l}\text { In \% } \\
55.1 \%\end{array}$} & \multicolumn{2}{|l|}{ Respondents } & \multirow{2}{*}{$\begin{array}{l}\text { Total } \\
55\end{array}$} & \multirow{2}{*}{$\frac{\text { In \% }}{13.3 \%}$} \\
\hline Gender & Male & & & \multirow[t]{6}{*}{ University name } & Hung Vuong & & \\
\hline & Female & 185 & $44.9 \%$ & & Hai Phong & 68 & $16.5 \%$ \\
\hline & Total & 412 & 100 & & Hong Duc & 170 & $41.3 \%$ \\
\hline \multirow{6}{*}{$\begin{array}{l}\text { Choosing } \\
\text { intention } \\
\text { from }\end{array}$} & Grade 10 & 23 & $5.6 \%$ & & Sai Gon & 65 & $15.8 \%$ \\
\hline & Grade 11 & 45 & $10.9 \%$ & & An Giang & 54 & $13.1 \%$ \\
\hline & Grade 12 & 340 & $82.5 \%$ & & Total & 412 & 100 \\
\hline & \multirow[t]{2}{*}{ Others } & \multirow[t]{2}{*}{4} & \multirow[t]{2}{*}{$1.0 \%$} & \multirow[t]{7}{*}{ Information from } & Websites & 43 & $10.4 \%$ \\
\hline & & & & & Acquaintences & 89 & $21.6 \%$ \\
\hline & Total & 412 & 100 & & Teachers & 44 & $10.7 \%$ \\
\hline \multirow{4}{*}{$\begin{array}{l}\text { Family } \\
\text { monthly } \\
\text { income }\end{array}$} & $<10$ mil VND & 139 & $33.7 \%$ & & Counselors & 72 & $17.5 \%$ \\
\hline & $10-15$ mil VND & 211 & $51.2 \%$ & & $\begin{array}{l}\text { Marketing } \\
\text { Documents }\end{array}$ & 85 & $20.6 \%$ \\
\hline & $>15$ mil VND & 62 & $15.0 \%$ & & Others & 79 & $19.2 \%$ \\
\hline & Total & 412 & 100 & & Total & 412 & 100 \\
\hline
\end{tabular}

According to the results of the above summary, it can be seen that, most students have choice of university from their senior year of grade 12, accounting for $82.5 \%$. The majority of students participating in the survey have a monthly family income of less than 15 million VND. Only $15 \%$ of students have a monthly family income of over 15 million. There are 170 students participating in the survey of this study are in Hong Duc University (Thanh Hoa), accounting for $41.3 \%$. The remaining proportion is relatively even among the remaining universities, namely Hung Vuong, Hai Phong, Saigon and An Giang University. Regarding the admissions information channel, $21.6 \%$ of students knew and chose the school through acquaintances, while $20.6 \%$ of students considered choosing the school through advertising channels; $17.5 \%$ of students know the information through counselors and only $10.7 \%$ of students followed their teachers' advice.

Using SPSS software to evaluate the reliability of the scale using Cronbach's Alpha reliability coefficient, the results showed that the measurement scale met the standard requirement because of Cronbach's Alpha coefficient from 0.777 to 0.937 . In addition, when considering the correlation coefficient of the total variable, the results showed that all observed variables have a correlation coefficient from 0.575 or more. Therefore, it can be concluded that the measurement scale used to collect data of the research model is very high standard. No variable was excluded from the innitial scale. The results of the reliability testing of scales are presented in the following tables:

Table-2. Cronbach's Alpha coefficient

\begin{tabular}{l|l|l}
\hline Factors & No of ob. variables & Cronback's Alpha \\
\hline Study Major & 3 & 0.859 \\
\hline Quality and Reputation & 3 & 0.911 \\
\hline Costs & 3 & 0.896 \\
\hline Influence Group & 3 & 0.777 \\
\hline Facility and Location & 3 & 0.937 \\
\hline Promotional Activity & 3 & 0.887 \\
\hline Decision to choose local university & 3 & 0.903 \\
\hline
\end{tabular}

The factor analysis is carried out with the method of Principal components analysis with the method of Varimax rotating (rotating the element angles to minimize the number of large coefficients at the same factor, thus increasing the ability to interpret factors) and stopping when extracting elements with Eigenvalue is 1.

Table-3. Kaiser-Meyer-Olkin Measure

\begin{tabular}{l|l|l}
\hline \multicolumn{2}{l|}{ Kaiser-Meyer-Olkin Measure of Sampling Adequacy. } & $\mathbf{. 7 3 2}$ \\
\hline \multirow{3}{*}{ aartlett's Test of Sphericity } & Approx. Chi-Square & 3325.351 \\
\cline { 2 - 3 } & df & 153 \\
\cline { 2 - 3 } & Sig. & .000 \\
\hline
\end{tabular}


The KMO (Kaiser-Meyer-Olkin) is an indicator used to consider the suitability of factor analysis. The research model consists of 6 groups of influential factors with 18 observed variables influencing university selection. The results of factor analysis showed that the coefficient $\mathrm{KMO}=0.732>0.5$ and $\mathrm{p}=0.000$, proving that the Exploratory Factor Analysis (EFA) is an appropriate method, at the same time determining the number of groups of factors extracted during the analysis. With Eigenvalues criteria $>1$, the results showed that the element groups remained the same (not separated into new groups) and the six extracted element groups could explain up to $82.438 \%$ of the variation of the data. The results of factor rotation are shown in the following Table 4:

Table-4. Factor Rotation

\begin{tabular}{|c|c|c|c|c|c|c|}
\hline & \multicolumn{6}{|c|}{ Component } \\
\hline & 1 & 2 & 3 & 4 & 5 & 6 \\
\hline Faci2 & .952 & & & & & \\
\hline Facil & .923 & & & & & \\
\hline Faci3 & .922 & & & & & \\
\hline Quali3 & & .939 & & & & \\
\hline Quali2 & & .863 & & & & \\
\hline Quali1 & & .856 & & & & \\
\hline Cost2 & & & .930 & & & \\
\hline Cost 1 & & & .887 & & & \\
\hline Cost 3 & & & .868 & & & \\
\hline Promo3 & & & & .869 & & \\
\hline Promo2 & & & & .860 & & \\
\hline Promo1 & & & & .800 & & \\
\hline Major3 & & & & & .891 & \\
\hline Major2 & & & & & .872 & \\
\hline Major1 & & & & & .863 & \\
\hline Influ2 & & & & & & .905 \\
\hline Influ3 & & & & & & .799 \\
\hline Influ1 & & & & & & .781 \\
\hline
\end{tabular}

Results of Table 4 showed that all observed variables had factor load greater than 0.5 so the observed variables continue to be used in the research model. In addition, through factor analysis, the observed variables in the scale were not separated into new groups, which meaned that the scales met the standards and had high reliability.

Table-5. Test the suitability of the model

\begin{tabular}{l|l|l|l|l}
\hline Model & R & R Square & Adjusted R Square & Std. Error of the Estimate \\
\hline 1 & $.795(a)$ & .632 & .624 & .417 \\
\hline
\end{tabular}

In order to identify, measure and evaluate the influence of the six groups of factors obtained from the exploratory factor analysis (EFA), the author conducted analysis of the multivariate linear regression using SPSS software. The regression result has a value of $\mathrm{R} 2=0.624$, which indicates that the independent variables in the model can explain $62.4 \%$ of the variation of the dependent variable. Therefore, it can be concluded that the relevance of the model is relatively high.

Table-6. Coefficients ${ }^{\mathrm{a}}$

\begin{tabular}{|c|c|c|c|c|c|c|}
\hline \multicolumn{2}{|c|}{ Model } & \multicolumn{2}{|c|}{ Unstandardized Coefficients } & \multirow{2}{*}{$\begin{array}{l}\text { Standardized } \\
\text { Coefficients } \\
\text { Beta }\end{array}$} & \multirow[t]{2}{*}{$\mathbf{t}$} & \multirow[t]{2}{*}{ Sig. } \\
\hline & & B & Std. Error & & & \\
\hline \multirow[t]{7}{*}{1} & (Constant) & .579 & .452 & & 1.281 & .201 \\
\hline & $\mathrm{X} 1$ & .241 & .053 & .227 & 2.547 & .000 \\
\hline & $\mathrm{X} 2$ & .153 & .054 & .128 & 2.374 & .000 \\
\hline & $\mathrm{X} 3$ & .396 & .239 & .328 & 2.484 & .001 \\
\hline & $\mathrm{X} 4$ & .183 & .145 & .170 & 1.412 & .004 \\
\hline & $\mathrm{X} 5$ & .129 & .041 & .095 & 1.858 & .000 \\
\hline & X6 & .083 & .055 & .075 & 1.522 & .000 \\
\hline
\end{tabular}

Multivariate linear regression equations can be written as follows:

$$
Y=0.227 . X 1+0.128 . X 2+0.328 . X 3+0.170 . X 4+0.095 . X 5+0.075 . X 6
$$

Through the regression model obtained, all 06 groups of factors of the research model have an influence on the student's decision to choose a local university in the descending order of impact as follows: Costs (0.328), Study Major, Influence Group, Quality and Reputation, Facilities and Promotional Activity.

\section{Conclusion}

Based on the theoretical model, the study has designed and tested a scale of factors affecting the decision to choose a university in Vietnam. The results of exploratory factor analysis are extracted into 06 groups of factors with 18 observed variables. Eigenvalues are all greater than 1 and the explained variance accumulates over $50 \%$ of the 
variation of the observed variables. Both 6 groups of factors influence a student's decision to choose a university. The research model explains $62.4 \%$ for the overall relation of the above 6 groups of factors with the decision to choose a local university in Vietnam. Because this is the first type of applied research conducted exclusively for local universities, the results cannot be compared with published studies. In addition, it may be due to limited information, space and time of implementation, so the study is limited in the number of samples studied. Although the results of the study also point out some of the key factors that influence the decision on local university choice with statistical significance, in reality, it is possible that there are other groups of factors that influence the decision to choose a local university in Vietnam. The above limitations also open the way for further research on the factors affecting student's local university choice in Vietnam.

\section{References}

Bromley (2004). Influences and motivations on which students base their choice of career. Loughborough university, UK. Journal of Research in Education, 72: 47-59. Available:

https://repository.lboro.ac.uk/articles/The_influences_and_motivations_on_which_students_base_their_cho ice_of_career/9475862

Chapman, D. W. (1981). A model of student college choice. The Journal of Higher Education, 52(5): 490-505.

Dahari and Muhamad, A. (2011). Factors influencing international students' choicetowards universities in Malaysia. African Journal of Business Management, 5(26): 10615-20.

Hackett (1994). Toward a unifying social cognitive theory of career and academic interest, choice, and performance. Journal of Vocational Behavior, 45(1): 79-122.

Hemsley-Brown, J. and Oplatka, I. (2006). Universities in a competitive global marketplace. International Journal of Public Sector Management, 19(4): 316-38.

Hoang, T. and Chu, N. M. N. (2008). Analyze research data with SPSS. Hong Duc publisher: HCM City.

Joseph, S. K. M. (2010). Institutional factors influencing students' college choice decision in Malaysia: A conceptual framework. International Journal of Business and Social Science, 1(3): 53-58.

Kotler and Fox (1995). Strategic Marketing for Educational Institutions. Upper Saddle River: NJ: Prentice-Hall.

Le Quang, H., 2013. "Local university in Vietnam, the status and development orientation." In International Conference Report at University of Khonken Thailand.

Maringe, F. (2006). University and course choice. International Journal of Educational Management, 20(6): $466-79$.

Nguyen, M. H. (2011). Factors affecting students choosing open university - ho chi minh city, scientific research topic of ho chi minh city. Open University.

Parasuraman, Berry and Zeithaml. (1991). Perceived service qualtiy as a customer-based performance measure: An empirical examination of organizational barriers using an extended service quality model. Human Resource Management. 335-64.

Sander, P., Stevenson, K., King, M. and Coates, D. (2000). University students' expectations of teaching. Studies in Higher Education, 25(3): 309-23.

Tran, V. Q. and Cao, H. T. (2009). Factors affecting high school students' decision to select a university. Journal of Science and Technology Development, 15(12): 87-102.

Zeithaml, V. A. and Bitner, M. J. (1996). Services marketing. McGraw-Hill: New York. 